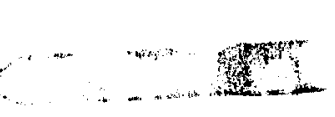

\title{
CONSOLIDATED RESEARCH PROGRAM, UNITED STATES GULF COAST GEOPRESSURED-GEOTHERMAL PROGRAM
}

\section{Technical Progress Report}

Third Quarter 1992

\section{DISCLAIMER}

This report was prepared as an account of work sponsored by an agency of the United States Government. Neither the United States Government nor any agency thereof, nor any of their employees, makes any warranty, express or implied, or assumes any legal liability or responsibility for the accuracy, completeness, or usefulness of any information, apparatus, product, or process disclosed, or represents that its use would not infringe privately owned rights. Reference herein to any specific commercial product, process, or service by trade name, trademark, manufacturer, or otherwise does not necessarily constitute or imply its endorsement, recommendation, or favoring by the United States Government or any agency thereof. The views and opinions of authors expressed herein do not necessarily state or reflect those of the United States Government or any agency thereof.
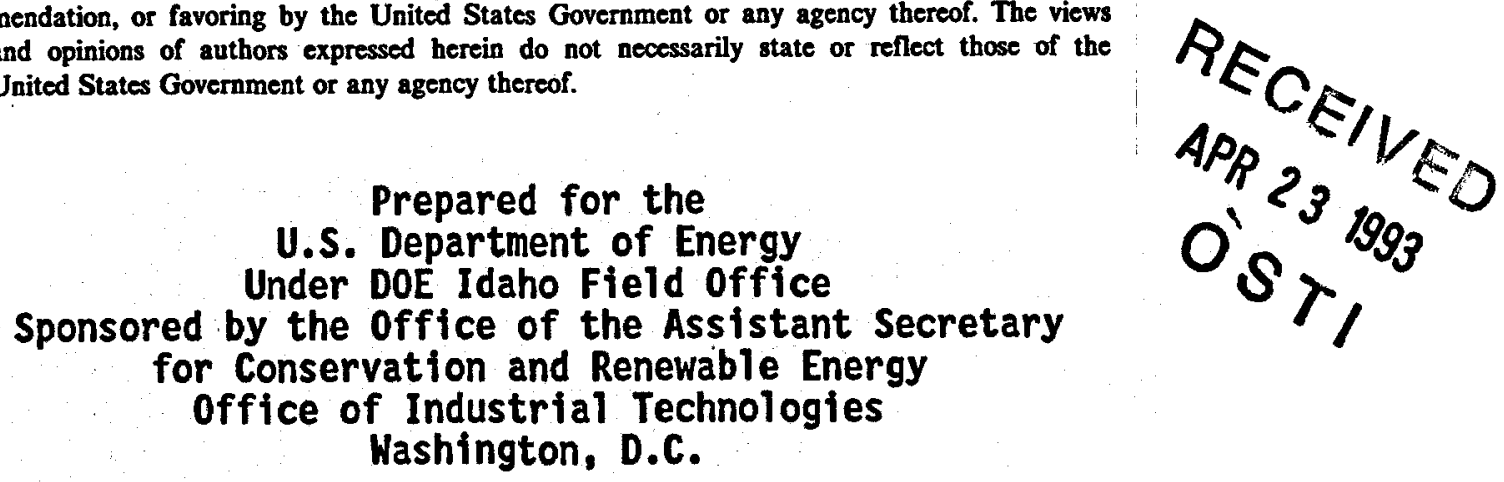

Prepared by

The University of Texas at Austin

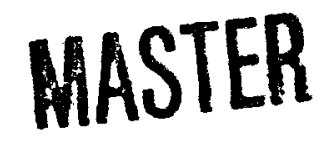




\section{DISCLAIMER}

This report was prepared as an account of work sponsored by an agency of the United States Government. Neither the United States Government nor any agency Thereof, nor any of their employees, makes any warranty, express or implied, or assumes any legal liability or responsibility for the accuracy, completeness, or usefulness of any information, apparatus, product, or process disclosed, or represents that its use would not infringe privately owned rights. Reference herein to any specific commercial product, process, or service by trade name, trademark, manufacturer, or otherwise does not necessarily constitute or imply its endorsement, recommendation, or favoring by the United States Government or any agency thereof. The views and opinions of authors expressed herein do not necessarily state or reflect those of the United States Government or any agency thereof. 


\section{DISCLAIMER}

Portions of this document may be illegible in electronic image products. Images are produced from the best available original document. 


\section{CENTER FOR PETROLEUM AND GEOSYSTEMS ENGINEERING FOURTH QUARTERLY REPORT OCTOBER, NOVEMBER, DECEMBER 1992}

January 21, 1993

Management Report 78

Report Period: October 1, 1992 - December 31, 1992

CONTRACT TITLE: Consolidated Research Program, United States Gulf Coast Geopressured-Geothermal Program

CONTRACT NUMBER: DE-FC07-85NV10412

CONTRACTOR NAME: Center for Petroleum and Geosystems Engineering

Bureau of Economic Geology

The University of Texas

CPE 2.502

Austin, Texas 78758

CONTRACT PERIOD: February 13, 1991 - December 31, 1992

\section{RESEARCH AREAS AND CONTRACT TASKS:}

\section{Rock Mechanics}

Work is in progress on the final report.

\section{Reservoir Engineering}

During the last quarter, work has focused on developing a numerical model to approximate the flow characteristics of the Gladys McCall reservoir. Various reservoir models have been used in the study to simulate the well transient pressure and pressure derivative behavior during the reservoir production period. The pressure behavior of the 1983 Reservoir Limits Test (RLT) was closely matched by an elongated linear reservoir model with the well located off-center.

The matching procedure appears to provide reasonable estimates of the probable configuration of Gladys McCall reservoir geometry. Double-slope pressure behavior (on a semilog plot) develops after the early radial flow period, indicating the existence of a no-flow boundary near the well. At later times, linear flow character (square-root-time straight line) becomes clear when two closer boundaries are both felt at the well.

The formation permeability and the distance between the well and the no-flow boundary are obtained by analyzing the semilog pressure plot of the RLT drawdown test. The short time pressure transient behavior of a well in a long, narrow reservoir is the same as that of an infinite reservoir, because at short time the well does not feel the effect of the no-flow boundaries. As shown in Fig. 1, a semilog plot of wellbore pressure vs. time yields a straight line of slope 11 psi cycle, indicating early radial flow. The duration of this infinite acting period can be confirmed from the first horizontal portion of the pressure derivative log-log plot, shown in Fig. 2. As soon as effect of the nearest boundary is felt at the well, the well pressure deviates from this straight-line trend. A second straight line is observed in Fig. 3 (a magnified plot of Fig. 1). The slope of this line is nearly twice that of the early-time straight line. This is characteristic of pressure 
behavior shown by well in the vicinity of a sealing fault. The distance to the fault is obtained from the intersection-time, $t_{x}$, between these two straight lines by ${ }^{1}$,

$$
d=0.01217 \sqrt{\frac{k t_{x}}{\varphi \mu c_{t}}}
$$

which gives a distance of $260 \mathrm{ft}$ for $\mathrm{t}_{\mathrm{x}}=0.6 \mathrm{hr}$ shown on Fig. 2 .

Linear flow solutions have been discussed extensively by many authors. ${ }^{2-7}$ The transient linear flow for a constant rate case can be analyzed using the following equation,

$$
\mathrm{p}_{i}-\mathrm{p}_{\mathrm{wf}}=8.129 \frac{\mathrm{qB}}{\mathrm{hw}} \sqrt{\frac{\mu}{\varphi k c_{t}}} \sqrt{\mathrm{t}}
$$

where $p_{i}$ is reservoir initial pressure, $p_{w f}$ is wellbore pressure, $q$ is flow rate, $w$ is reservoir width, $h$ is the reservoir thickness, and $c_{t}$ is the total compressibility of reservoir fluid. According to this equation, a plot of wellbore flowing pressure versus square root of flowing time yields a straight line of slope $8.129 \frac{\mathrm{gB}}{\mathrm{hw}} \sqrt{\frac{\mu}{\varphi k c_{t}}}$, which allows a calculation of the channel width, w. The linear flow regime is also characterized by a $1 / 2$ slope pressure derivative on the log-log plot. Figures 4 and 2 illustrates the linear flow characters, i.e., square-root-time straight line and $1 / 2$ slope log-log plot, for the RLT drawdown test on wellbore pressure and pressure derivative plots, respectively. A reservoir width of $1900 \mathrm{ft}$ is calculated.

Based on the above analysis, linear models with various sizes have been used in the study to match the transient pressure and pressure derivative behavior of the 1983 RLT test. The model found to match is $19,000 \mathrm{ft}$ by $1,900 \mathrm{ft}$ by $332 \mathrm{ft}$, with the well located $4,500 \mathrm{ft}$. to one end and $260 \mathrm{ft}$. from one lateral side of the reservoir. Figure 5 shows a schematic diagram of the model. The drawdown and buildup pressure plots generated by the model are given in Figs. 1, 2, 4,6, and 7. They show good agreement with field data. However, this model can not account for the kh changes and water influx observed from later buildup tests. Ongoing studies are investigating the effect of reservoir layering, near-wellbore damage, naturally fractured systems, as well as aquifer geometry on both transient pressure behavior and reservoir response.

\section{REFERENCES}

1. Gray, K.E.: "Approximating Well-to-Fault Distance From Pressure Buildup Tests," J. Pet. Tech., (July 1965), 761-67.

2. Ehlig-Economides, C. and Economides, M.J.: "Pressure Transient Analysis in an Elongated Linear Flow System," Soc. Pet. Eng J., Dec. 1985, 839-47.

3. Kohlhaas, C.A. and Abbott, W.A.: "Application of Linear and Spherical Flow Analysis Techniques to Field Problems-Case Studies," paper SPE 11088 presented at the 57th Annual Fall Technical Conference and Exhibition of the Society of Petroleum Engineers of AIME, New Orleans, LA, Sept 26-29, 1982. 
4. Miller, F.G. : " Theory of Unsteady-State Influx of Water in Linear Reservoirs," Journal of the Institute of Petroleum; vol. 48, No. 467, Nov. 1962, 365-79.

5. Nabor, G.W.: "Linear Aquifer Behavior," J. Pet. Tech., (May, 1964), 561-3.

6. Nutakki, R. and Mattar, L.: "Pressure Transient Analysis of Wells in Very Long Narrow Reservoirs," paper SPE 11221 presented at the 57th Annual Fall Technical Conference and Exhibition of the Society of Petroleum Engineers of AIME, New Orleans, LA, Sept 26-29, 1982.

7. Wong, D.W., Mothersele, C.D., and Harrington, A.G.: "Pressure Transient Analysis in Finite Linear Reservoirs Using Derivative and Conventional Techniques: Field Examples," paper SPE 15421 presented at the 61 th Annual Fall Technical Conference and Exhibition of the Society of Petroleum Engineers of AIME, New Orieans, LA, Oct. 5-8, 1986.

\section{Geological Studies}

During the fourth quarter of 1992, work on geologic studies for the Guld Coast Geopressured-Geothermal Program involved final editing of a Bureau Geological Circular and geological and engineering analysis of field data for a large medium-oil field from the Mirando Trend.

The Geological Circular entitled Geothermal and Heavy-oil Reservoirs in Texas: Direct Use of Geothermal Fluids to Enhance Recovery of Heavy Oil is in final manuscript editing. All figures have been drafted and are in editing. The geophysical logs acquired for Prado Field in Jim Hogg County are being analyzed in order to characterize the producing reservoirs. A base map has been generated using a computerized geographic information system (ARCInfo). Computer manipulation of geologic and engineering information will greatly speed analysis of the large amounts of data and easee preparation of map products. Approximately 332 well logs have been entered into the database. Current activity involves creating a digital GIS system for mapping well log attributes and geologic parameters such as net sandstone, percent standstone, isopach, and structure of six producing horizons within the field. 


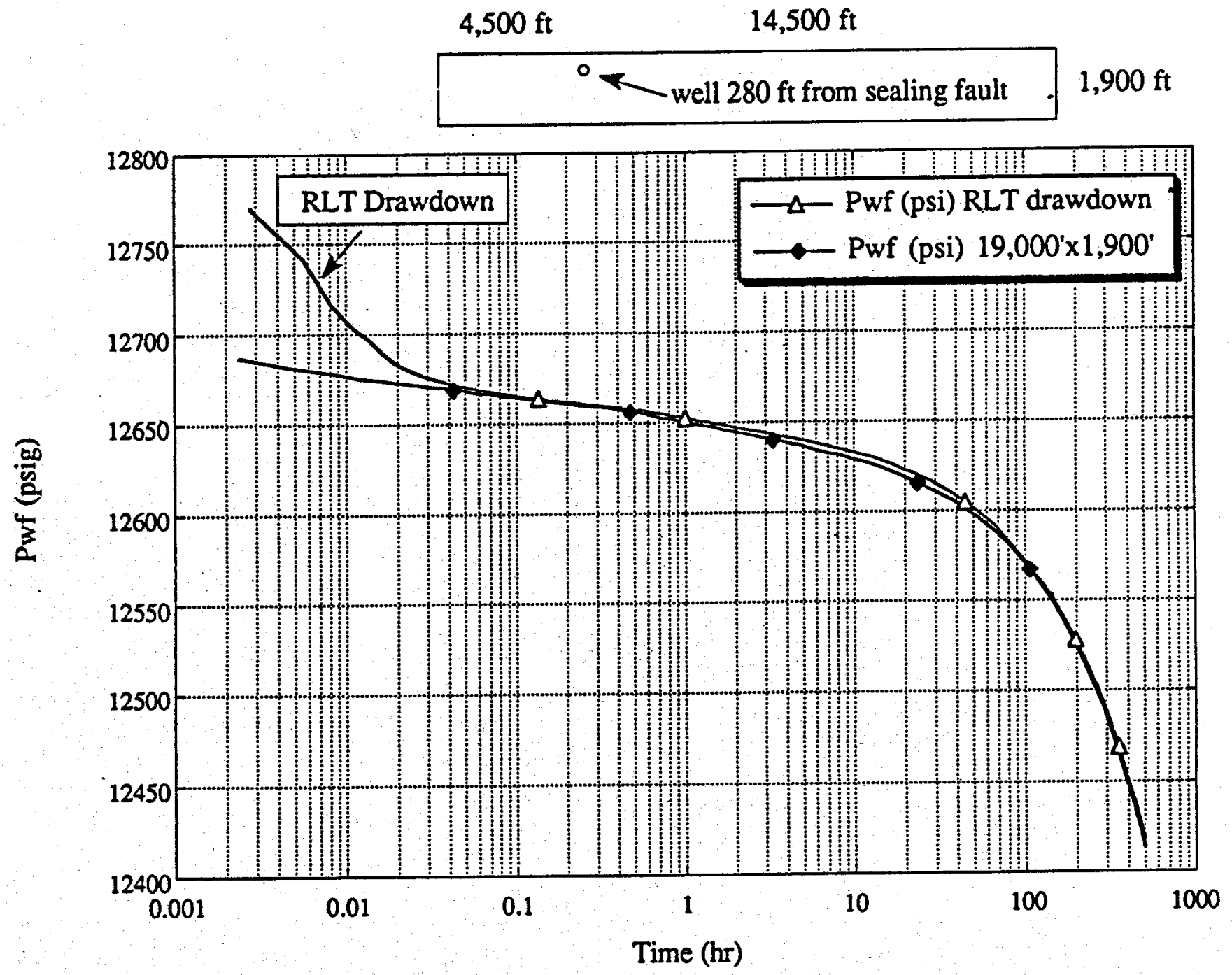

Fig. 1: 1983 RLT and model drawdown wellbore pressure vs. flowing time plot. 


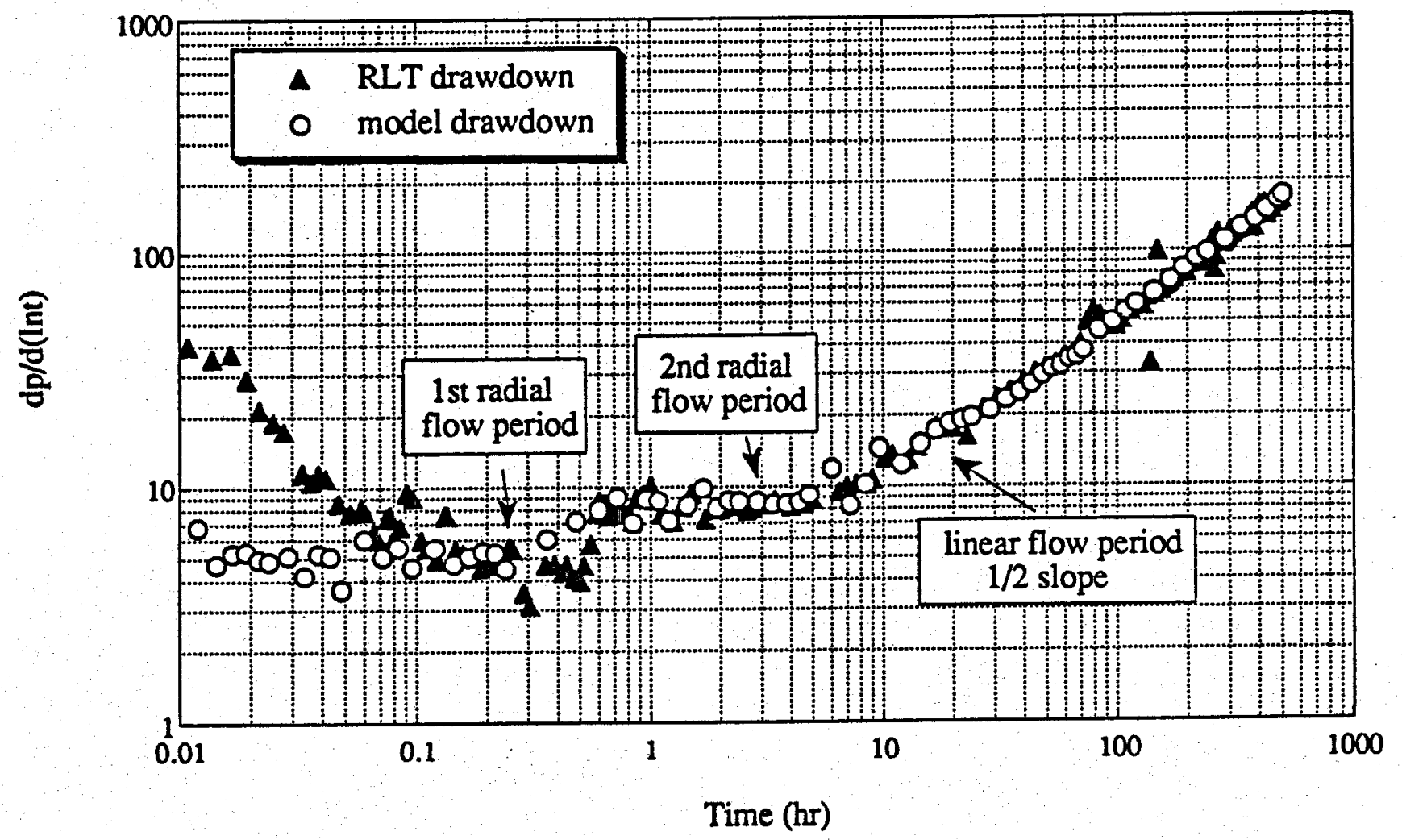

Fig. 2: 1983 RLT drawdown and model pressure derivative curves. 


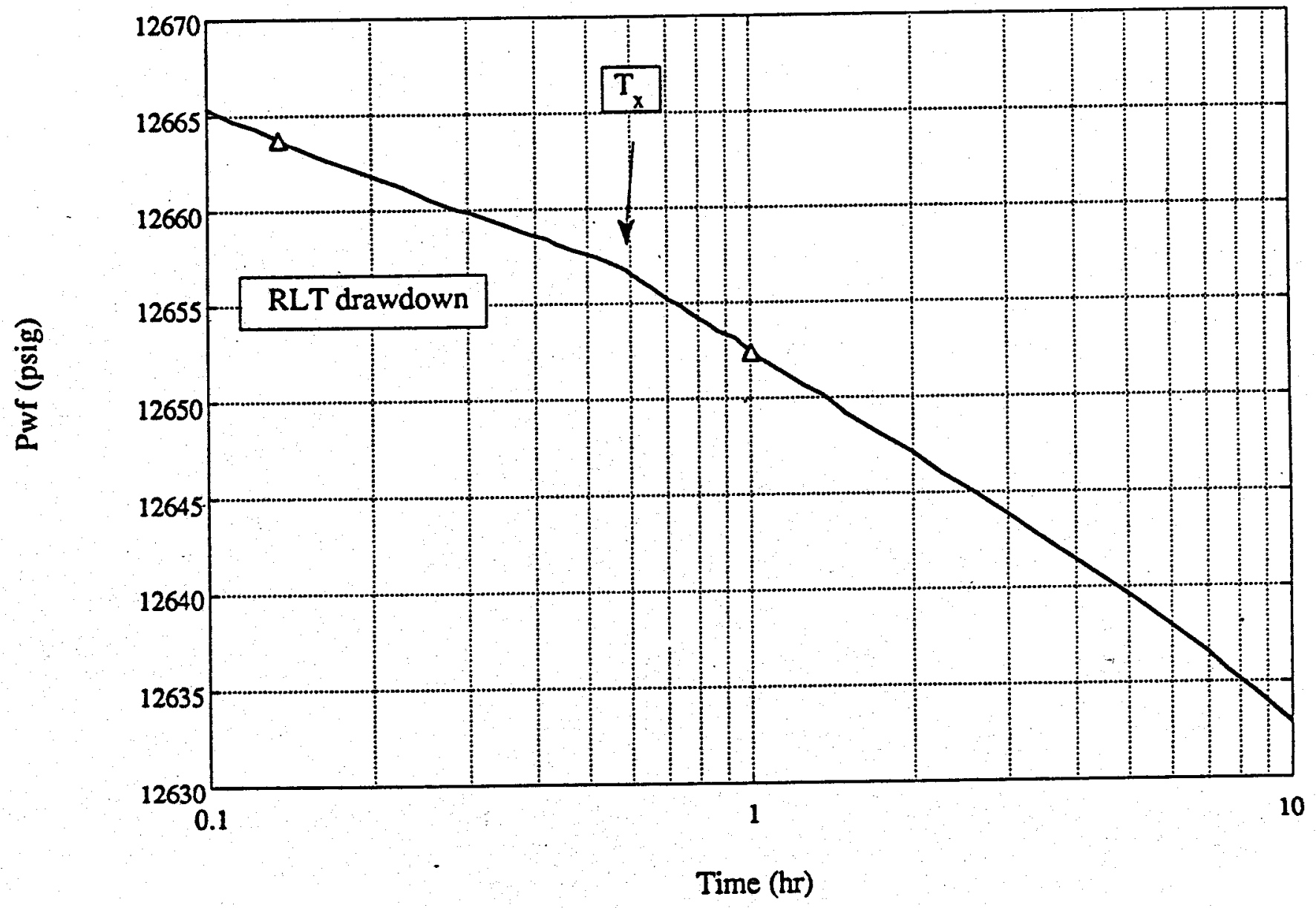

Fig. 3: 1983 RLT drawdown wellbore pressure vs. time plot. 


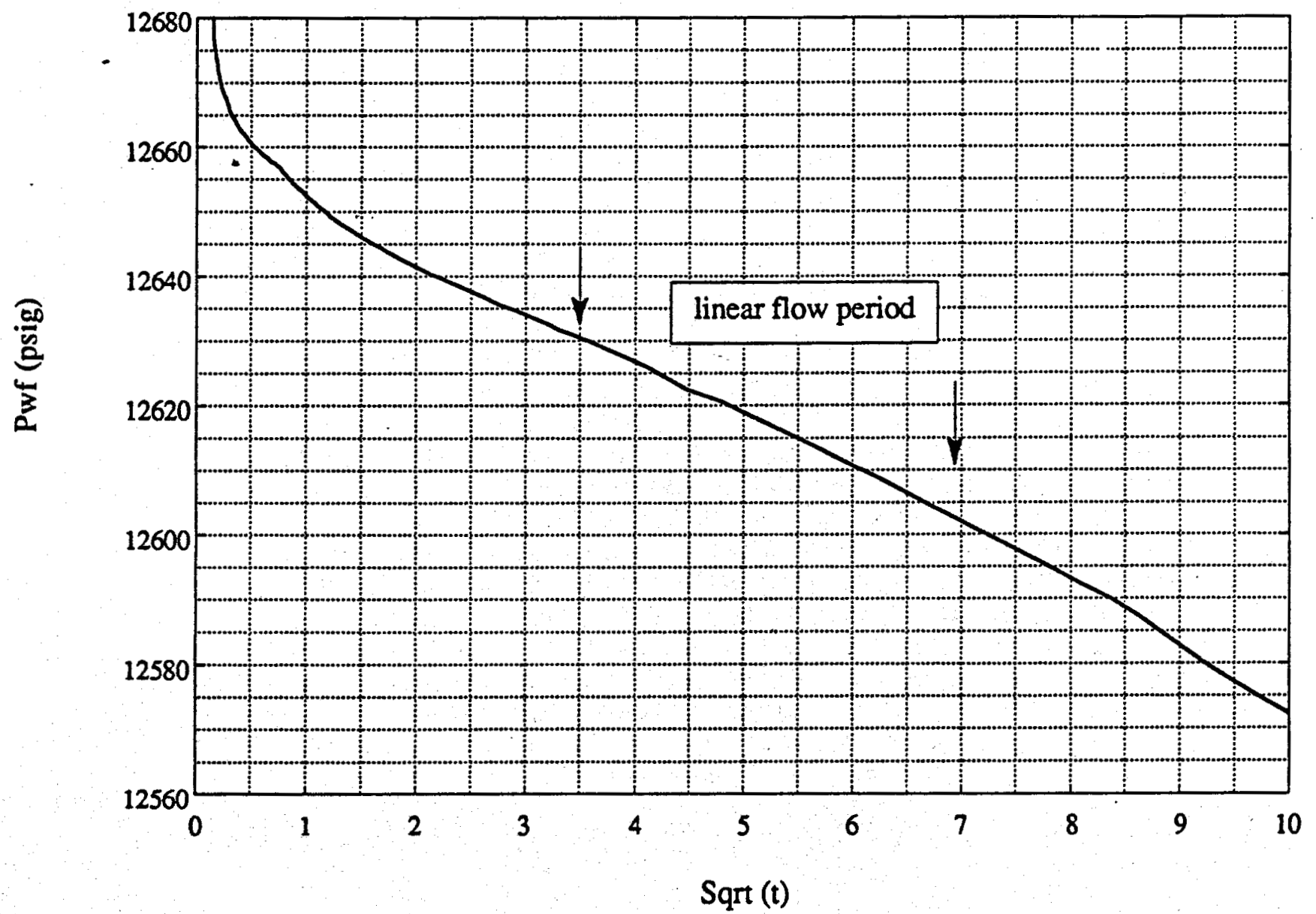

Fig. 4: 1983 RLT drawdown wellbore pressure vs. square root of flowing time plot. 
$\rightarrow \quad 4,500 \mathrm{ft}$
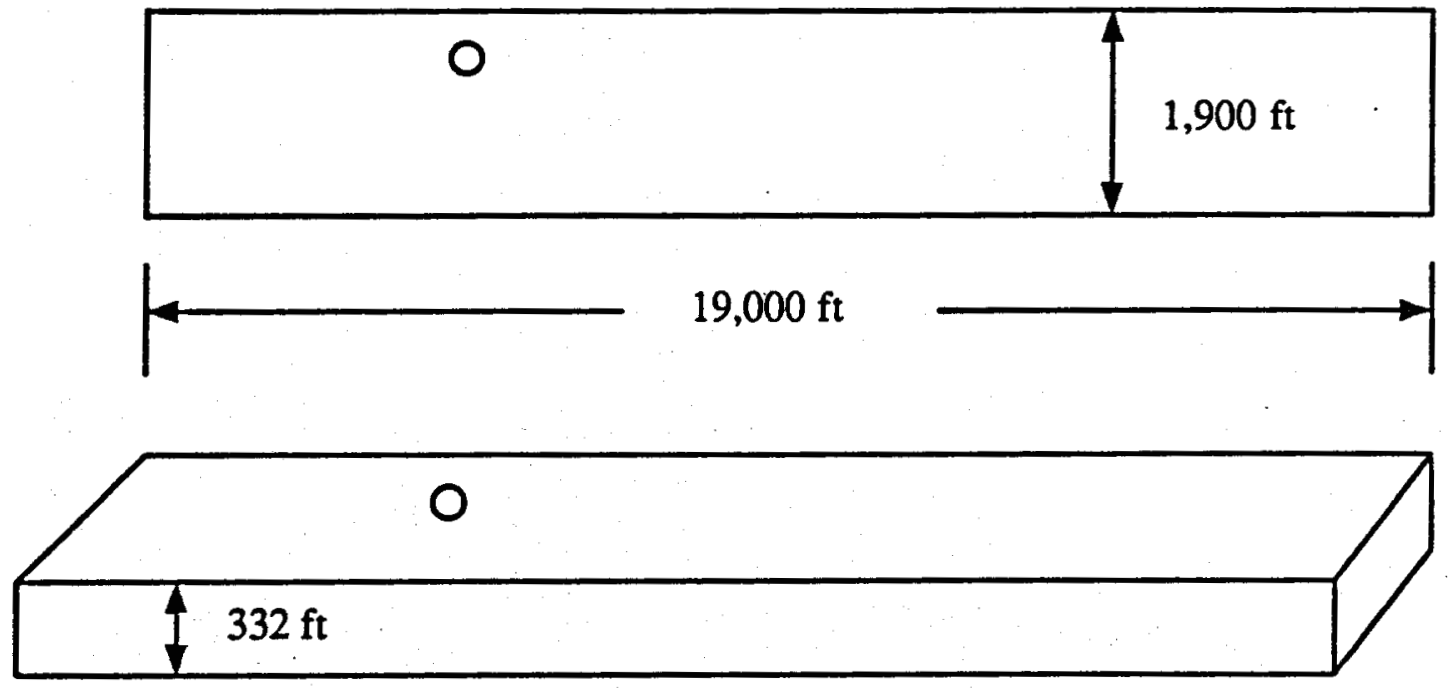

Fig. 5: Schematic diagram of Gladys McCall reservoir model. 


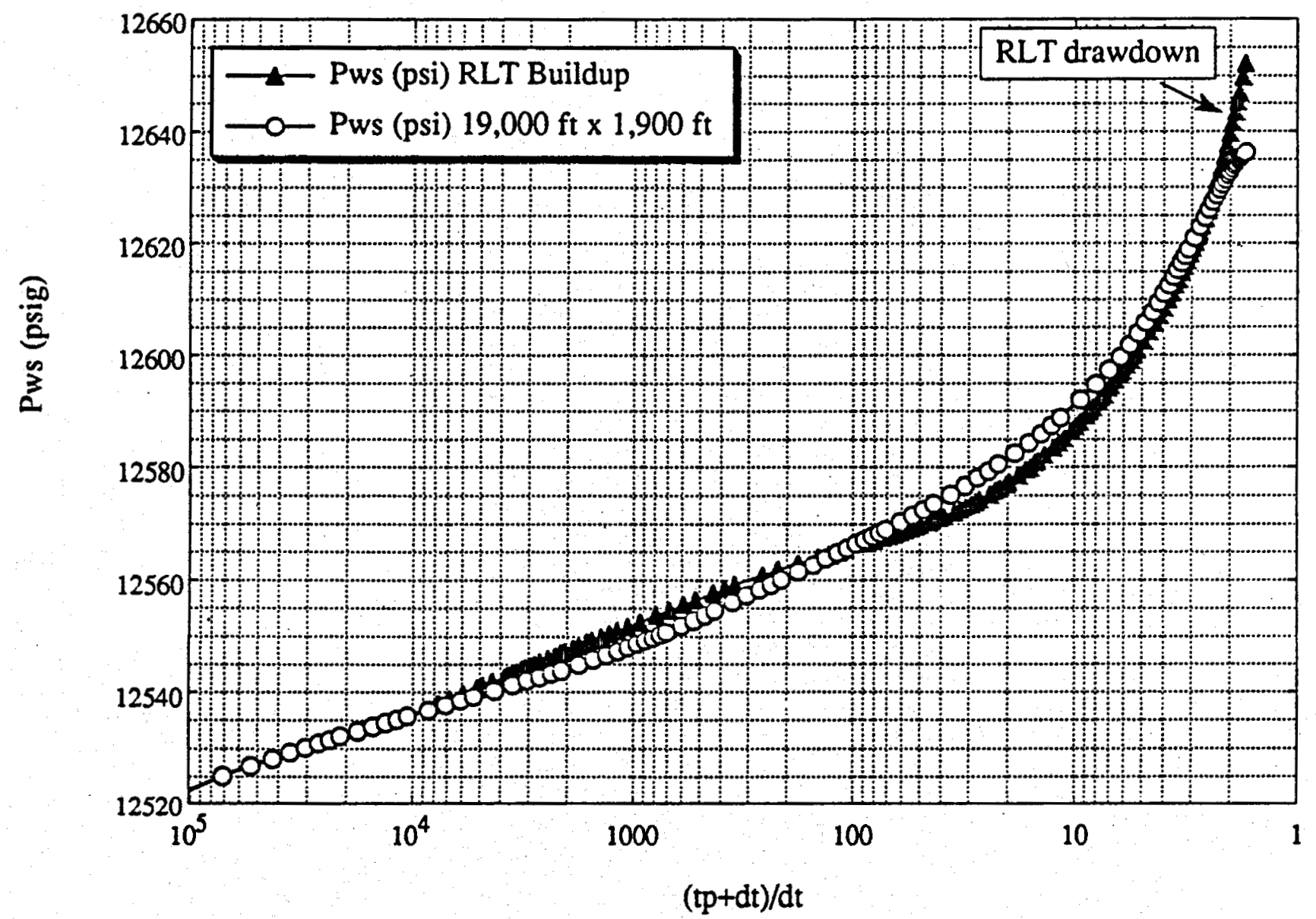

Fig. 6: 1983 RLT and model buildup pressure vs. Horner time plot. 


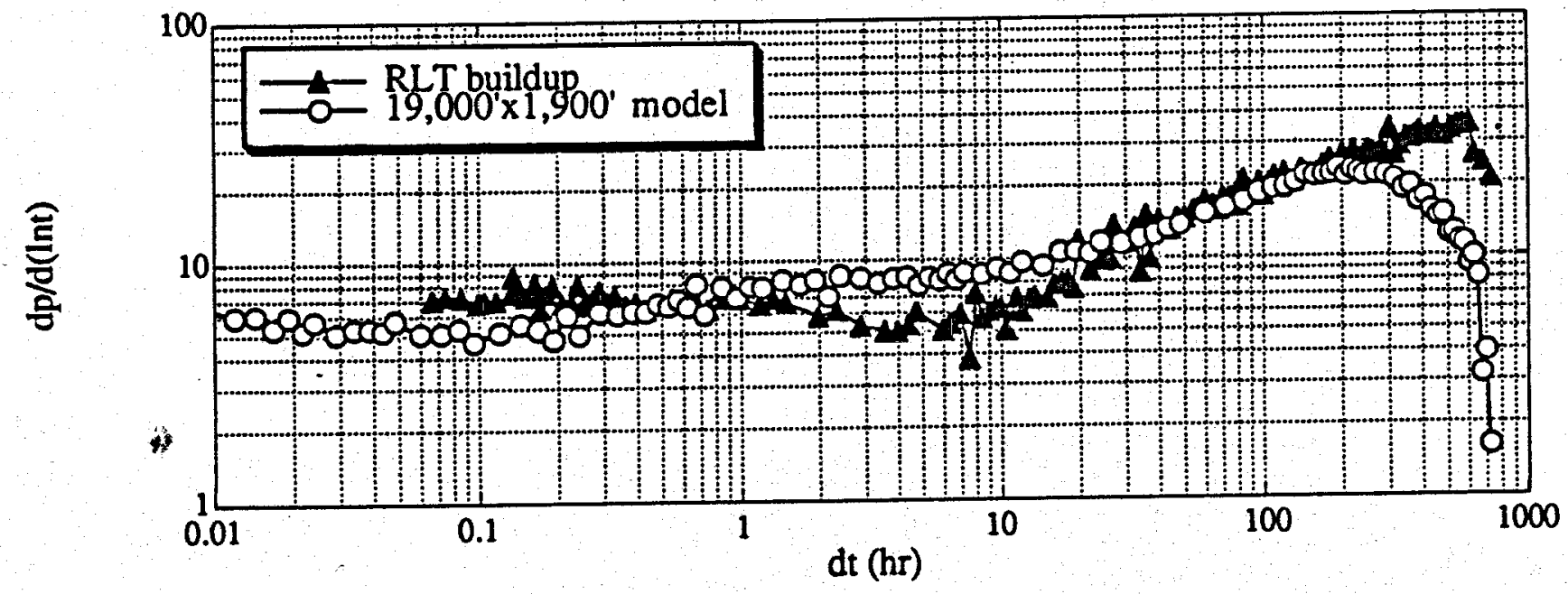

Fig. 7: 1983 RLT and model buildup pressure derivative plots. 